Ann. Génét. Sél. anim., I979, 11 (2), I6I-I63.

\title{
Note \\ An XO chromosome constitution in a sterile Mare (Equus caballus)
}

\author{
Liliane METENIER ( $\left.{ }^{1}\right)$, M.A. DRTANCOURT $\left({ }^{2}\right)$ and E.P. CRTBIU ( \\ (1) Laboratoire de Cytogénétique U.N.C.E.I.A.-I.N.R.A., \\ Centre national de Recherches zootechniques, \\ $7835^{\circ}$ Jouy-en-Josas (France) \\ (2) Station de Physiologie de la Reproduction, \\ Ceutre la Recherches de Tours, I.N.R.A., \\ 37380 Nouzilly (France)
}

\begin{abstract}
Summary
One case of $63, \mathrm{XO}$ chromosome constitution is described in a phenotypically normal but sterile mare with gonadal dysgenesis.

Several general descriptions of the karyotype of the Domestic Horse (Equus caballus) have been reported (ROTHEFELDS et al., I959; TRUJILLO et al., I962; SASAKI and Makino, I962 and Makino et al., I963). According to the idiogram established by DE GIOVANNI et al. (I979), the diploid number was 64 of which 6 pairs were submetacentric, 7 pairs metacentric, the $\mathrm{X}$ metacentric and the $\mathrm{Y}$ acrocentric.

In recent years, chromosome studies of Horse have generally been directed toward the association of chromosome alterations with phenotypic defects including those of the reproductive system (review of $\mathrm{DE}_{\mathrm{i}}$ GrovanNI and CRIBIU, I978). The best known example is the abnormal XO sex chromosome constitution reported by Chandley et al. (I975), Hughes et al. (r975) and Taylor and TrommersCHAUSEN-SMith (I975).

The present report describes the chromosome constitution of a sterile mare.

A phenotypically normal but apparently sterile female was admitted to the department of Physiology of the Reproduction of NouzILLY to be hemicastrated. The genital tractus appeared normal. As seen by rectal palpation, the ovary was very small, smooth, firm with no follicules on its surface; histological examination showed that it was completely devoided of follicules and thus fully made of stroma tissu only.
\end{abstract}


Blood samples were obtained from the jugular vein for chromosome analysis. Leucocytes were cultured and harvested according to MoORHEAD et al. (I960). C-banding was achieved by a modification of the technique of SUmNER (I972).

Chromosome preparations were observed with a Leitz-Ortholux microscope and photographs were taken on Kodak microfile film with a Leitz-Orthomat camera. The arrangement of the horse chromosomes in karyotype were made according to DE Grovanni et al. (I979).

All the 47 metaphases counted had a chromosome number of $2 n=63$ (fig. I). The C-banding metaphases showed this mare to have anormal autosomal complement and only one $\mathrm{X}$ chromosome.

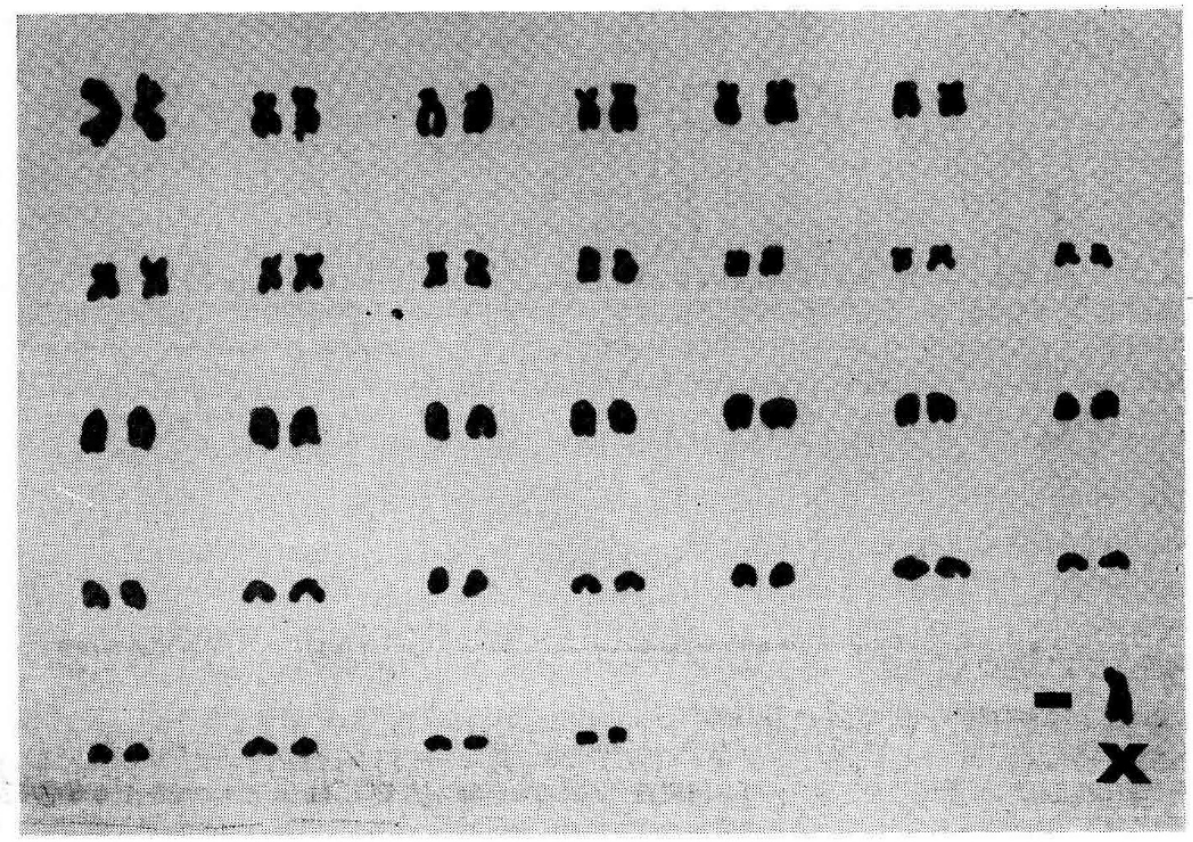

FIG. I. - Karyotype of the sterile mare.

One can see the 62 autosoms and the only $X$ chromosome below right.

Caryotype de la jument stérile.

On distingue les 62 autosomes et, en bas à droite, l'unique chromosome $X$.

The abnormal XO sex chromosome constitution is well known in man and it can caused by either paternal or maternal non-disjunction. Affected individuals are phenotypic females but usually display infantile sexual development and /or assortment of somatic abnormalities (Turner's Syndrome) and are sterile.

All the XO mares reported by CHANDLEY et al. (I975), Hughes et al. (I975) and TAYLOR and TROMMERSCHAUSEN-Smith (I975) did not vary from our case. They were phenotypically normal female and had inactive ovaries (or not ovary) lacking germ cells.

Our data demonstrate that cytogenetic tests could be a valuable tool to explain potential infertility in mares. 


\section{Acknowledgments}

We thank Dr. C.P. Popescu (Laboratoire de Cytogénétique U.N.C.E.I.A.-I.N.R.A., C.N.R.Z., Jouy-en-Josas, France) for helpful discussions and critical reviews of the manuscript.

\section{Résumé}

\section{Une jument stérile (Equus caballus) de caryotype, XO}

Une jument stérile, phénotypiquement normale mais présentant une dysgénie gonadique a été trouvée porteuse d'une monosomie pour le chromosome sexuel $\mathrm{X}$.

\section{References}

Chandley A. C., Fletcher J., Rossdale P. D., Peace C. K., Richetts S. W., Mc Enery R. J., Thorne J. P., Short R. V., Allen W. R., 1975. Chromosome abnormalities as a cause of infertility in mares. J. Reprod. Fert., 23, 377-383.

De Grovanni A., Cribiu E. P., i978. Le anomalie cromosomiche nel cavallo (Equus caballus). Zootec. nutr. anim., 4, 9-16.

De Grovanni A., Molteni L., Succi G., Castiglioni M., Cribiu E. P., i979. The idiogram of the domestic horse (Equus caballus L.). Caryologia, 32, 2 I 5-222.

Hughes J. P., Kennedy P. C., Benirschke K., 1975. XO-Gonadal Dysgenesis in the Mare (Report of two cases). Equine Vet., 7, ro9-II2.

Makino S., Sofun I. T., Sasaki M. S., I963. A revised study of the chromosomes in the horse, the ass and the mule. Proc. Jap. Acad., 39, I76-18r.

Moorhead P. S., Nowel P. C., Mellman W. J., Battips D. M., Hungerford D. A., i96o. Chromosome preparations of leucocytes cultured from human peripheral blood. Exp. Cell Res., 20, 6r3-6r6.

Rothfels K. H., Axelrad A. A., Siminovitch L., Mc Culloch E. A., Rarker R. C., I959. The origin of altered cell lines from mouse, monkey and man, as indicated by chromosome and transplantation studies in R. W. Bigg Can. Cancer Conf., Academic Press, New York, 3, I 89-2 I 4.

SASA KI M. S., Makino S., I962. Revised study of the chromosome of domestic cattle and the Horse in somatic cells in vitro. J. Heved., 53, I 57-162.

Sumner A. T., 1972. A simple technique for demonstrating centromeric heterochromatin. Exp. Cell Res., 75, 304-306.

Taylor N. J., Trommerschausen-Smith A., i975. Equine karyotyping. Proc. first int. Symp, Equine Hemato., I24-13I.

Trujillo J. M., Stenius C., Christian L. C., Ohno S., ig62. Chromosomes of the horse, the donkey and the mule. Chromosoma, 13, 243-248. 